\title{
THE ANALGESIC AND BONE HEALING EFFECTS OF TRANSCUTANEOUS ELECTRICAL NERVE STIMULATION
}

\author{
By \\ El-Ghaweet, ${ }^{\star}$ A. ; Nagwa, Helal ${ }^{\star *}$; \\ El-Batouty, M.M. ${ }^{\star \star *}$ and El-Mogy, S. ${ }^{* \star * *}$ \\ From \\ The Physical Medicine*, Patholoyy**, Orthopaedic \\ Surgery ${ }^{* * *}$, and Radiology ${ }^{* * * *}$ Departments . \\ Faculty of Medicine, Mansoura University. \\ Received for Puplication : 3/12/1990.
}

\section{INTRODUCTION}

During the period of fracture immobilization, early rehabilition program, including exercise, is essential (Kathrins, 1982). This will speeds the rate of reduction of swelling and tenderness, minimizes fibrosis and atrophy and keeps tendons gliding (Schafer, 1983). The appropriate and effective rehabilitation program may be hampered by the presence of post-fracture pain. An ideal analgesic method to be used in orthopaedic surgery would be one that controls pain without having detrimental effects on fracture healing. Non-steroidal anti-inflammatory drugs(NSAIDs) are commonly used on an empirical basis for pain relief in these patients (Scott et al., 1984). At the same time many other studies proved the deleterious effect of NSAIDs on fracture healing (Allen et al., 1980 El-Batouti et al., 1984 ; Tornkvist, 1985 and Keller et al., 1987).

Alternative methods of pain relief are available but none has been adopted as routine practice. Transcutaneous electrical nerve stimulation (TENS) has none of the side effects of drug therapy and the advantage of continuous admistration (Gilbert et al., 1986). A compact and light TENS apparatus which is convenient and easy MANSOURA MEDICAL JOURNAL 
to use has recently been introduced , and if effective, would be of great benefit to the patient. This study described the effects of TENS on the relief of pain and bone healing after experimentaly induced fractures in rats. Regarding the analgesic and healing effects, TENS was compared with indomethacin as standard NSAID used for post-fracture pain relief.

\section{MATERIAL AND METHODS}

Ninety Albino rats (average weight 129 grams) were used. Under ether anaesthesia, the right forelimb of each animal was manually fractured, using digital pressure over a fulcrum. On the day following the fracture procedure, the rats were divided randomly into three equal groups. The rats in group I underwent transcutaneous electrical nerve stimulation on the anteroposterior sides of the fractured ends. Transcutaneous electrical nerve stimulation was applied from Neuro Pulse (Hirose Electric Co. LTD, Japan) stimulator at a stimulation frequency of 80 $\mathrm{Hz}$, a pulse duration of $0.4 \mathrm{~ms}$ and an intensity of $15 \mathrm{~mA}$ through conduction rubber silicon electrodes coated with conducting gell. Electrical stimulation was given for 30 minutes every day. The rats in group II received a daily dose of $0.75 \mathrm{mg}$ of indomethacin $/ \mathrm{kg}$ adminstered intragastrically by a special stomach canula (El-Sayed, 1988). The rats in group III were not given any line of treatment and allowed to heal spontaneously. The animals were kept in standard conditions with free supplies of food and water. Ten animals from each of the three groups were sacrificed at 1,2 and 3 ,ecks after the fracture.

Assessment of pain threshold using analgesymeter was done on the second day after fracture and immediately before sacrification of rats. Pressure was applied by an analgesymeter apparatus at the supported site of fracture untill the rat either squeaked or attempted to withdraw the limb under a iree weight that increased at a constant rate. This force was continuously monitored by a pointer moving along a linear scale (Randal \& Selitto, 1957 and Takeusue et al., 1969).

Radiographic assessment for each

Volume 21, 1991 
fractured forelimb was done for each rat immediately before sacrification. These films were done without knowledge of the treatment regimen. Points were given for the stage of healing on a scale from one to four for the following : early callus formation, good callus formation, early healing with callus margins well seen and early trabeculation, or healed fracture (Low, 1985).

The rats were anaesthetized with ether and sacrified for autopsy for the histopathological assessment of each fractured forelimb. Autopsy was limited to removal of the fractured forelimbs by severing at the carpus and cubitus. The tissue was fixed in 10 percent formalin. Decalcification of bone according to Greep et al.,(1948) method was performed. The specimens were embeded in paraffin and sections were cut and stained with Haematoxylin and Eosin. All the histologic sections were examined at random sequence without knowledge of the treatment regimen. The degree of farcture healing was determined using a 5 point scale (Allen et al., 1980): Grade $\mathrm{O}=$ Non union $;$ Grade I = in- complete cartilagenous union, due to retension of fibrous elements in the cartilagenous plate; Grade 2 = complete cartilagenous union (a wellformed plate of hyaline cartilage unites the fragments); Grade $3=$ incomplete bony union due to the presence of a small amount of cartilage in the callus . Grade $4=$ complete bony union.

Comparison between pain threshold, radiological and histological healing scors of the fractures in the different groups and with the same fracture duration, were made using Student's t-test of significance.

\section{RESULTS}

* There was an occurrance of two deaths in the group of rats treated with indomethacin prior to day 21. However, there was no occurrance of any deaths among the rats in the remaining groups.

* Pain threshold was not a significant point of difference observed among the three groups at the start of the trial (Table 1). 
* One and two weeks after fracture, a significant improvement in pain threshold was observed in the groups treated with TENS and indomethacin, when compared with that before treatment or after the same peroids in the control group.

However within the third week of fracture, a significant improvement in pain threshold was observed in the control group. After the third week, no significant difference in pain threshold was observed after comparing that of the control group with either that of the TENS or indomethacin treated group (Table 1, 2).

* The group of rats that received TENS showed higher degrees of radiological and histological bone healing scores when compared with either of the control or indomethacin treated groups (Table 3,4 and Fig. 1 - 6).

* The group of rats treated with indomethacin showed lesser degrees of radiological and histological bone healing scores when compared with either control or TENS treated groups (Table 3,4 and Fig. 1 - 5).

* Inflammatory cells and blood vessels were observed at the site of fracture in the group of rats receiving TENS to the same extent as that observed in the control group (Fig. 2,3).

* Decreased cellular infiltration and vascularization was observed at the site of fracture in the rats subjected to indomethacin treatment, when compared with that of the control or TENS treated groups. (Fig. 1, 2).

\section{DISCUSSION}

Pain relief was an important goal for the effective, early rehabilitation program during the period of fracture immobilization(Kathrins, 1982). An ideal analgesic method to be used would be that which controls pain without having detrimental effects on the process of fracture healing. Our 
results indicate that transcutaneous electrical nerve stimulation offers satisfactory post-fracture analgesia equal to that of indomethacin. Concomitant to this analgesic effect, TENS was associated with enhancement of the bone healing process in contrast to indomethacin which proved to retard bone healing.

The analgesic effect of TENS was explained by Taub (1974 and Wyke, 1976) who emphasized the blocking mechanism of electrical currents on Cfibre mediated pain which supply the periosteum and cancellous bone. Bloedel and McCreery (1975) observed that large myelinated fibres have a low threshold to electrical stimulation, thus its early stimulation closes the spinal gate and thus prevents painful peripheral stimuls from gaining access to the ascending transmission system. An alternative explanation for the ability of TENS to produce anaigesia is based upon the premise that stimulation causes release of endorphins which subsequently attach to receptors and inhibit transmission of noxious stimuli (Snyder, 1977 and
Solomon, 1980). The proved analgesic effect of TENS in our study in agreement with that of Pike (1978) who used TENS following hip surgerg.

The mechanism by which electrical current stimulate fracture healing remains obscure . Nannmark et al., (1985) proved that electric current can stimulate osteogenic cells. Roaze and Hinsenkamp (1982 \& 1985) found that electrostimulation can increase glycoaminoglycans synthesis and growth of bone rudiments. More recently Cochran et al., (1985) and Grenshaw (1987) demonstrated that bone has natural electric properties which stimulate the process of osteogenesis. When bone is electrically stimulated, the source of the electricity is external, whereas the source in naturally healing bone is internal. The external source of electricity appears to initiate healing in a manner identical to that initiated by the naturally induced electrical current (Friedenberg and Brighton, 1987). The observations made in the present study showed that TENS do not impair cellular infiltration or vascularity at the fracture site. This 
cellular infiltration is very important for the initiation of bone healing as these cells begin to produce new cells which differentiate and organize to provide new vessels, fibroblasts, chondroblasts and osteoblasts (Frost, 1989). Our results were in agreement with that of Nannmark et al., (1985) who found that electrical stimulation may give rise to an early inflammatory reaction in bones as well as in soft tissues and that this reaction may be hampered by the administration of indomethacin.

Our results indicate that indomethacin offers satisfactory post-fracture analgesia. The is perhaps due to analgesic, anti-inflammatory and antiprostaglandin actions, which may exert an effect upon the post-fracture tissue reaction and result in a lesser degree of perceived pain (Yrjola et al., 1988).

The presence of cellular infiltration and prostaglandins at the site of fracture are the most important factors for bone healing (Dekal et al., 1981 and Simmons, 1985). It is therefore not Volume 21, 1991 surprising that indomethacin delays fracture healing in our study. Our results are in agreement with that of Sudmann et al., (1979) and Keller et al., (1987) who proved that indomethacin inhibits bone healing secondary to reduction of blood flow and cellular infiltration.

The use of NSAIDs during the acute phase of fracture is better to be a voided as they can reduce the potential of the normal healing process and thereby actually prolong the phases of rehabilitation. The analgesic effect in these cases can be obtained by the use of TENS which proved to possess an analgesic effect equal to that of indomethacin and at the same time enhance the process of bone healing.

\section{SUMMARY}

The effects of TENS on the relief of pain and bone healing was studied after the performance of experimental fractures in rats. With regards to these actions, TENS was compared with indomethacin as a commonly used drug for post - fracture pain relief. The right 
forelimb of 90 Albino rats was farc- analgesia equal to that of indomethatured and divided into three equal $\mathrm{cin}$, and at the same time enhances treatment groups. The first group re- the process of bone healing in conceived TENS, the second group re- trast to indomethacin which proved to ceived indomethacin while the rats in retard the healing process. It is possigroup 3 were left to heal spontaneous- ble to conclude that TENS is a signifily without any line of treatment. Pain cant adjunct for simulataneous postthreshold, radiological and histological fracture analgesia and enhancement healing scores were determined for of bone healing process and thereby Each rat. TENS offers satisfactory actually shortens the phases of rehabilitation. 
Table (1): The level of significance between anaigesymeter pressure at start of treatment and each observation period.

\begin{tabular}{|c|c|c|c|c|}
\hline $\begin{array}{l}\text { Observation } \\
\text { period ( days ) }\end{array}$ & $\begin{array}{l}\text { Group I } \\
\text { (TENS ) }\end{array}$ & $\begin{array}{c}\text { Group II } \\
\text { (Indomethacin ) }\end{array}$ & $\begin{array}{l}\text { Group ill } \\
\text { (Control) }\end{array}$ & $\begin{array}{c}\text { Statistical Significance } \\
\text { between }\end{array}$ \\
\hline 1 & $\begin{array}{c}0.901 \pm 0.392 \\
(n=30)\end{array}$ & $\begin{array}{c}1.103 \pm 0.469 \\
(n=30)\end{array}$ & $\begin{array}{c}1.096 \pm 0.467 \\
(n=30)\end{array}$ & $\begin{array}{ll}1-1111 & \text { N.S. } \\
1-111 & \text { N.S. } \\
1-111 & \text { N.S. }\end{array}$ \\
\hline 7 & $\begin{array}{l}\text { 2. } 124 \pm 0.458 \\
(n=30)\end{array}$ & $\begin{array}{c}2.235 \pm 0.539 \\
(n=29)\end{array}$ & $\begin{array}{c}1.234 \pm 0.432 \\
(n=30)\end{array}$ & $\begin{array}{l}1-11 \quad \text { N.S. } \\
1>111 \quad P<0.001 \\
11>111 P<0.0001\end{array}$ \\
\hline 14 & $\begin{array}{c}3.013 \pm 0.591 \\
(n=20)\end{array}$ & $\begin{array}{c}2.924 \pm 0.403 \\
(n=18)\end{array}$ & $\begin{array}{c}1.301 \pm 0.462 \\
(n=20)\end{array}$ & $\begin{array}{ll}1-11 & \text { N. S. } \\
1-111 & P<0.001 \\
11-111 & P<0.001\end{array}$ \\
\hline 21 & $\begin{array}{c}3.062 \pm 0.384 \\
(n=10)\end{array}$ & $\begin{array}{c}3.031 \pm 0.295 \\
(n=8)\end{array}$ & $\begin{array}{c}2.961 \pm 0.234 \\
(n=10)\end{array}$ & $\begin{array}{ll}1-11 & \text { N.S. } \\
1-111 & \text { N.S. } \\
11-111 & \text { N.S. }\end{array}$ \\
\hline
\end{tabular}

Table ( 2 ) : Analgesymeter pressure before and after treatment at each observation period.

\begin{tabular}{|c|c|c|c|c|c|c|}
\hline $\begin{array}{c}\text { Observation } \\
\text { Period } \\
\text { (days) }\end{array}$ & \multicolumn{2}{|c|}{ Group 1 } & \multicolumn{2}{|c|}{ Group II } & \multicolumn{2}{|c|}{ Group III } \\
\cline { 2 - 7 } & $n$ & TENS & $n$ & Indomethacin & $n$ & Control \\
\hline 1 & 30 & $0.910 \pm 0392$ & 30 & $1.103 \pm 0.465$ & 30 & $1.096 \pm 0.467$ \\
7 & 30 & $2.124 \pm 0.458$ & 29 & $\begin{array}{c}2.325 \pm 0.539 \\
P 1<0.001\end{array}$ & 30 & $\begin{array}{c}1.234 \pm 0.432 \\
\text { N.S. }\end{array}$ \\
& 20 & $\begin{array}{c}3.013 \pm 0.591 \\
p 2<0.001\end{array}$ & 18 & $\begin{array}{c}2.924 \pm 0.403 \\
p 2<0.001\end{array}$ & 20 & $\begin{array}{c}1.301 \pm 0.462 \\
\text { N.S. } \\
14\end{array}$ \\
21 & 10 & $\begin{array}{c}3.062 \pm 0.384 \\
p 3<0.001\end{array}$ & 8 & $\begin{array}{c}3.031 \pm 0.295 \\
p 3<0.001\end{array}$ & 10 & $\begin{array}{c}2.961 \pm 0.394 \\
p 3<0.001\end{array}$ \\
\hline
\end{tabular}


Table (3) : Radiological fracture healing score at each observation period.

\begin{tabular}{|c|c|c|c|c|}
\hline \multirow{2}{*}{$\begin{array}{l}\text { Observation } \\
\text { Period } \\
\text { (days) }\end{array}$} & Group 1 & Group II & & \multirow{2}{*}{$\begin{array}{c}\text { Statistical Significance } \\
\text { Between }\end{array}$} \\
\hline & TENS & (Indomethacin) & (Control) & \\
\hline 7 & $\begin{array}{c}2.367 \pm 0.595 \\
(n=30)\end{array}$ & $\begin{array}{c}0.624 \pm 0.793 \\
(n=29)\end{array}$ & $\begin{array}{c}1.415 \pm 0.681 \\
(n=30)\end{array}$ & $\begin{array}{l}I>\text { III } P<0.001 \\
I>\text { III } P<0.001 \\
I I<\text { III } P<0.001\end{array}$ \\
\hline 14 & $\begin{array}{c}3.391 \pm 0.598 \\
(n=20)\end{array}$ & $\begin{array}{l}1.127 \pm 0.641 \\
(n=18)\end{array}$ & $\begin{array}{c}2.724 \pm 0.713 \\
(n=20)\end{array}$ & $\begin{array}{l}I>\text { II } P<0.001 \\
\text { I }>\text { III } P<0.01 \\
\text { II }<\text { III } P<0.001\end{array}$ \\
\hline 21 & $\begin{array}{l}\text { 3. } 714 \pm 0.532 \\
(n=10)\end{array}$ & $\begin{array}{c}2.056 \pm 0.6138 \\
(n=8)\end{array}$ & $\begin{array}{l}\text { 3. } 611 \pm 0.729 \\
(n=10)\end{array}$ & $\begin{array}{l}I>\text { II } P<0.001 \\
I-\text { III N.S. } \\
\text { II }<\text { III } P<0.001\end{array}$ \\
\hline
\end{tabular}

Table (4) : Histological fracture - healing score at each observation period.

\begin{tabular}{|c|c|c|c|c|}
\hline \multirow{2}{*}{$\begin{array}{l}\text { Observation } \\
\text { Period } \\
\text { (days) }\end{array}$} & Group 1 & Group II & & \multirow{2}{*}{$\begin{array}{c}\text { Statistical Significance } \\
\text { Between }\end{array}$} \\
\hline & TENS & (Indomethacin) & (Control) & \\
\hline 7 & $\begin{array}{c}2.421 \pm 0.643 \\
(n=10)\end{array}$ & $\begin{array}{c}0.56 \pm 0.83 \\
(n=9)\end{array}$ & $\begin{array}{c}1.514 \pm 0.792 \\
(n=10)\end{array}$ & $\begin{array}{l}I>\text { III } P<0.001 \\
I>\text { III } P<0.001 \\
\text { II }<\text { III } P<0.025\end{array}$ \\
\hline 14 & $\begin{array}{c}3.502 \pm 0.782 \\
(n=10)\end{array}$ & $\begin{array}{c}1.032 \pm 0.714 \\
(n=10)\end{array}$ & $\begin{array}{c}2.589 \pm 0.646 \\
(n=10)\end{array}$ & $\begin{array}{l}I>\text { II } P<0.001 \\
I<\text { III N.S. } \\
\text { II }<\text { III } P<0.001\end{array}$ \\
\hline 21 & $\begin{array}{c}3.789 \pm 0.422 \\
(n+10)\end{array}$ & $\begin{array}{c}2.097 \pm 0.521 \\
(n=8)\end{array}$ & $\begin{array}{c}3.613 \pm 0.654 \\
(n=10)\end{array}$ & $\begin{array}{l}I>\| \mathrm{P}<0.001 \\
I-\text { III N.S. } \\
\text { II }<\text { III } P<0.001\end{array}$ \\
\hline
\end{tabular}




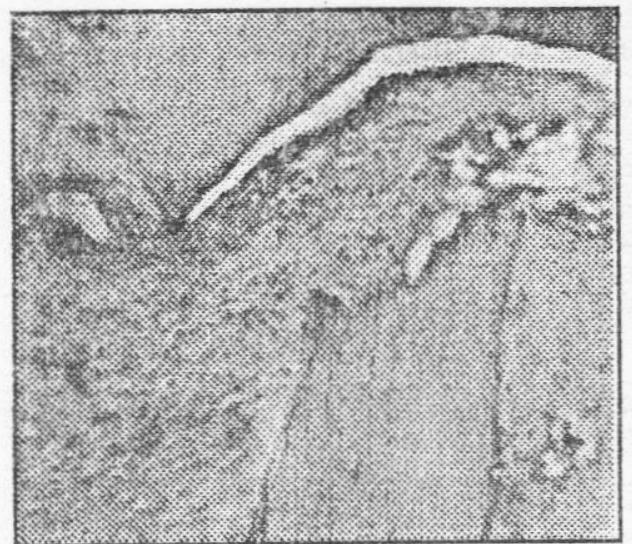

Fig. (I) : Section of the farctured area after two weeks of a rat received Indomethacin, showing non-union with fibrous tissue remenants, decreased cellular infiltration and decreased vascularity ( $\mathrm{Hx}$. \& $\mathrm{E}$. Stain $\times 100$ ).

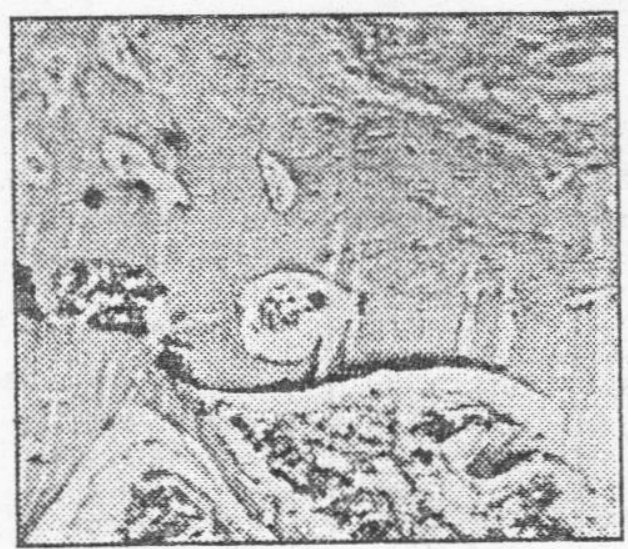

Fig. (2) : Section of the fractured area after two weeks, of a control a rat, showing incomplete cartilagenous union (grade I) with increased vascularity and cellular infiltration ( $\mathrm{Hx}$. \& E. stain $\times 100$ ).

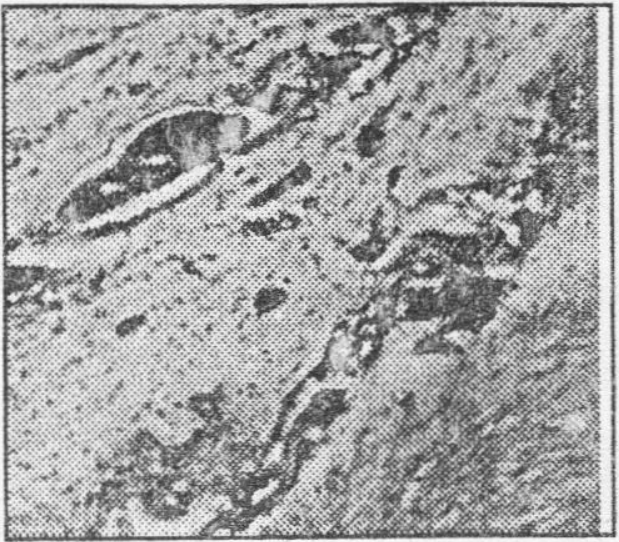

Fig. (3) : Section of the farctured area after two weeks of a rat treated with TENS, showing incomplete bony union (grade 3) with increased cellular infiltration and vascularity (Hx.\& E. stain, X 100).

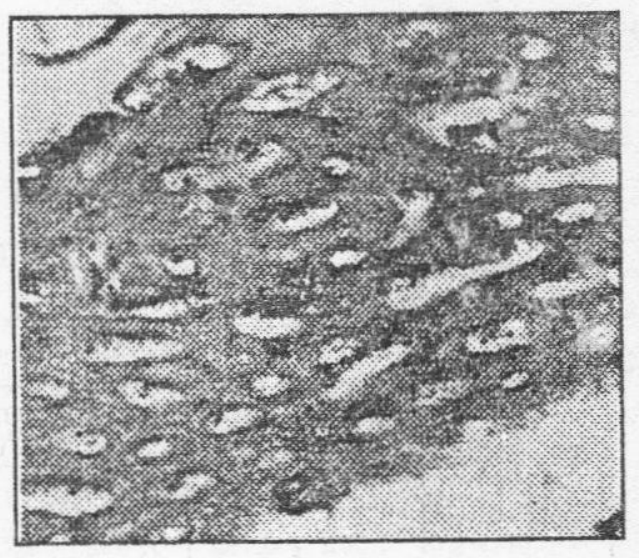

Fig. (4) : Section of the fractured area after three weeks of a control a rat, showing incomplete bony union (grade 3). (Hx.\& E. stain $X 100$ ).

Volume 21, 1991 


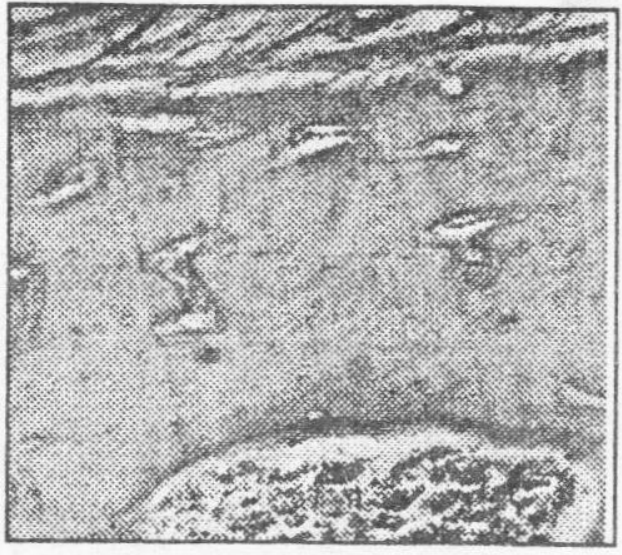

Fig. (5) : Section of the farctured area after three weeks of a rat treated with TENS, showing complete bony union (grade 4), (Hx.\& E. stain X 100).

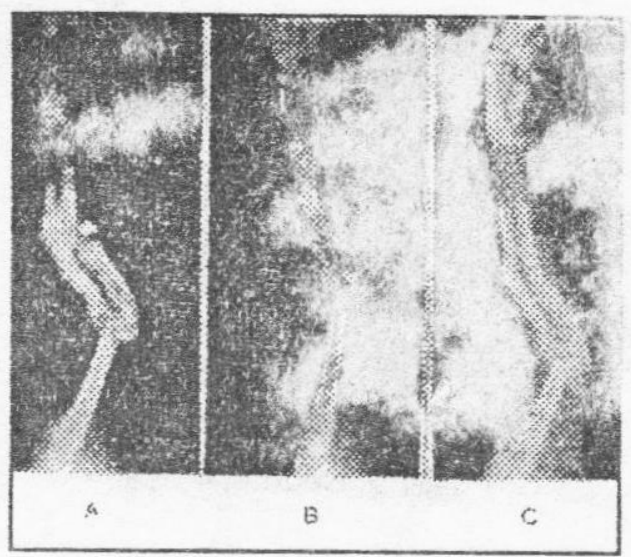

Fig. (6) : Roentgenograms of fractured tibia and fibula in the three groups after 3 weeks

a- Early callus formation (grade I) in a rat received indomethacin treatment.

b- Early healing with callus margins and early trabeculation (grade 3 ) in a control rat.

c- Heald fracture (grade 4) in a rat treated with TENS. 


\section{REFERENCES}

Allen, H.L. ; Wase, A. and Bear, W.T. (1980) : Acta. Orthop. Scand., $51: 595$.

Bloedel, J. and McCreaty, D. (1975) : Surg. Neurol., 4 : 65.

Cochran, C.V.; Johnson, M.V.; Kadaba, M.P.; Vosburgh, F.; Ferguson Pell, M.V. and Palmieri, V.R. (1985): J. Orthop. Res., $3: 508$.

Dekal, S. ; Lenthall, G. and Franci, M.J. (1981): J. Bone Joint Surg., 63 - B : 185.

El-Batouti, M.M. ; Basyouni, N. ; Abdel-Hamid, M.M. and Dahab, G.M. (1984): Mansoura Medical Bulletin, $12: 53$.

El-Sayed, H.I. ; El-Kholy, W. and ElGhaweet, A. (1988) : Mans. Sci. Bull, $15: 315$.

Friedenberg, Z.8. and Brighton, C.T. (1987) : In Fracture Volume 21, 1991 healing, Ed. Lane, I. M. Churchill Livingstone. New York, London, P. 75.

Frost, H. M. (1989) : Clinical Orthop. and Related research, 248 : 283.

Gilbert, J. M.; Gledhill, T. and George, L. (1986): Br. J. Surg., $73: 749$.

Greep, P. O.; Fisher, C.J. and Morse, A. (1948) : J. Am. Dent. Assoc., $63: 427$.

Grenshaw, A. H. (1987) : Campbell's operative orthropaedics Seventl. Ed. Crenshaw A.H. R.V. Mosby Company St. Louis Washington Toronto, P. 2112.

Kathrins, B. (1982) : Adult rehabilitation. First Ed. Logigian M. Little, Brown and Company Boston, P. 71.

Keller, J.; Bunger, C.; Andreassen, T. ; Bak, B. and Lucht, U. 
(1987) : Acta, Orthop.

Scard., $58: 379$.

Law, H.T.; Annan, I.; Mc Carthy, D.; Hughes, P. F.; Stead, A. C.; Camburn, M.A. and Montgomery, H. (1985) : J. Bone Joint . Surg., 46B - 67.

Nannmark, U.; Buch, F. and Albrektsson, T. (1985) : Acta Orthop. Scand., 56 : Simmons, D. J. (1985) : Clin. Orthop., 52.

Pike, P. N. H. (1978) : Anaesthesia, Snyder, S. H. (1977) : N. Eng. J. $33: 165$.

Randall, L. O. and Selitto, J.J. Solomon, R.; Viernstein, M. and (1957) : Arch. Int. Pharmacodyn., $111: 409$.

Roaze, M. and Hinsenkamp, M. Sudmann, E. and Bang, G. (1979): (1982) : Acte Orthop. Scand. Supp., $196: 51$.

Roaze, M. and Hinsenkamp, M. Takeusue, E.I. ; Schaefer, W. and (1985) : Preconstructive Surgery . S.Karger Basel, P. 87.

Schafer, R.C. (1983) : Chiropractic Med., $296: 266$. Long, D. (1980) : Surgery., $87: 142$.

management of sports and recreational injuries. Williams \& Wilkin's Baltimore / London, P. 190. cholas, J. (1984) : Principles of sports Medicine. Williams \& Wilkins Baltimore / London, P. 38. $200: 100$. Acte Orthop. Scand., 50 : $621-7$. Jukniewicz, E. (1969) : J. Pharma. Pharmacol., 21 788.

MANSOURA MEDICAL JOURNAL 
Taub, A. (1974) : Minn. Med., 57 : 172.

Tornkvist, H. ; Bauer, H.C. and Nils- (ed.) The lumbar spin and basic pain. Gruna \& Stratton. New York, P. 189. son, O.S. (1985) : Clin. Or- Yrjola, H.; Slivennoinen, 0.; Vilppu- thop.,193: 264.
Wyke, B. D. (1976) : In Jayson M.
son, O.S. (1985) : Clin. Or-
la, E. and Ahistrom-Beng,
E. (1988) : Acta . Orthop. Scand., $59: 43$. 


\title{
تأثيرات التنبية الكهريائى خلال الجلد فى تسكين الالم والتئام الكسور
}

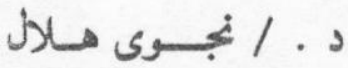 \\ د . م / عاطف الفويط

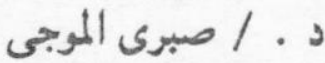

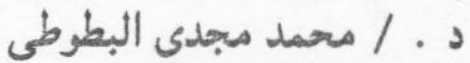

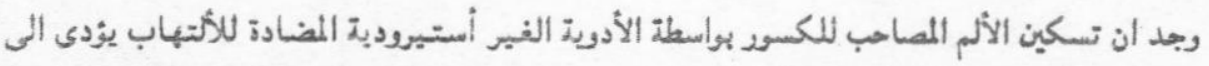

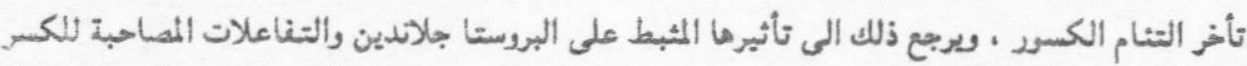

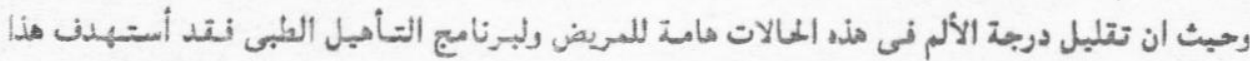

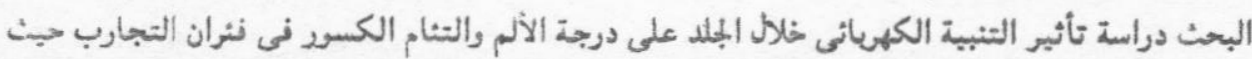

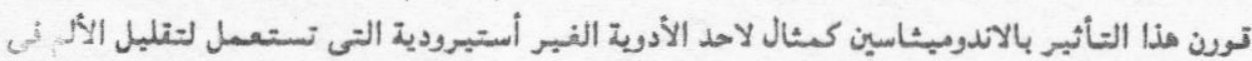

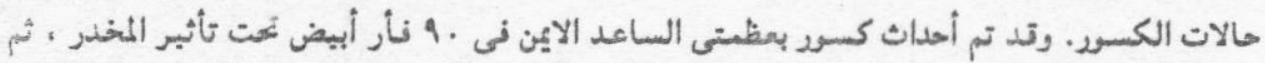

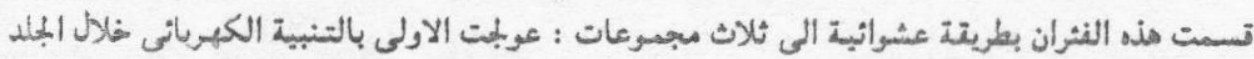

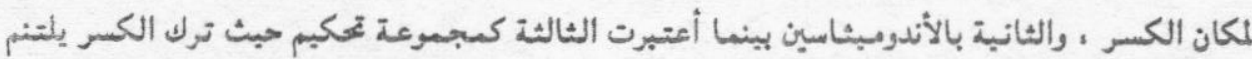

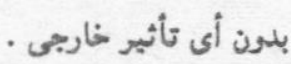

وتد تم متابعة الكسر أسبوعبا من حبث درجة المضض ودربة التثام الكسر بناء على الذحص

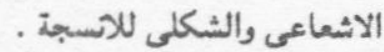

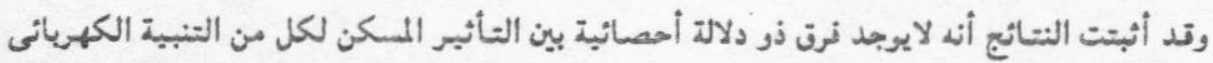

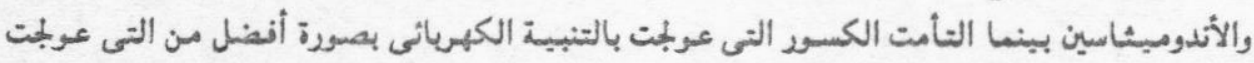

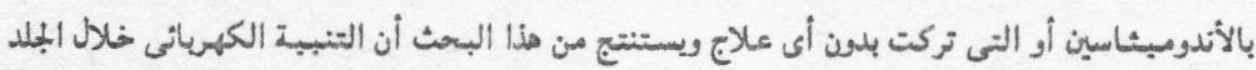

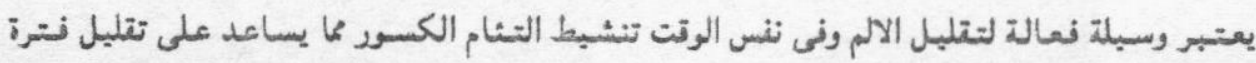

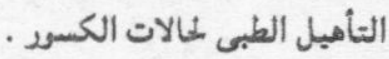


